\title{
IMPLEMENTASI PENEGAKAN KETENTUAN PIDANA TERHADAP PELANGGARAN HAK KEKAYAAN INTELEKTUAL REGIM HAK CIPTA
}

\author{
Dudung Indra Ariska \\ Universitas Wiralodra, Indramayu \\ Email: dudung90@gmail.com,
}

\begin{abstract}
Indonesia as an archipelago has a very rich diversity of cultural arts. This is in line with the diversity of ethnicity, trabs and religion as a whole is a national potential which needs to be protected. After the enactment of Law No. 19 of 2002, the creators in the field of literature and science received legal protection so that it is no longer turned off the creativity of its employees. Normatively, if there is piracy, the sanctions imposed are very severe, namely a seven-year prison sentence and / or a maximum fine of IDR 5,000,000,000.00 (five billion rupiah). In fact, piracy is still ongoing. The current development of piracy is due to law enforcement carried out by law enforcement officers in this case the police are not carried out thoroughly and thoroughly, or in other words run half-heartedly so that there is no single case of piracy in the film sector that can be used as jurisprudence.
\end{abstract}

Key word: Legal protection, piracy, jurispridence

\section{PENDAHULUAN}

Banyaknya pembajakan di bidang Hak Cipta lainnya menjadikan Indonesia sebagai surga bagi para pembajak sehingga pemegang Hak Kekayaan Intelektual banyak yang di rugikan. Hal tersebut di ungkapkan oleh Direktorat Jendral Hak Kekayaan Intelektual Departemen Kehakiman dan HAM Abdul Bari Azed. Keberadaan Hak Kekayaan Intelektual (HKI) dalam hubungan antar manusia dan antar Negara merupakan sesuatu yang tidak dapat dipungkiri. HKI juga merupakan sesuatu yang Given dan Inheren dalam sebuah masyarakat industri atau yang sedang mengarah kesana. Keberadaannya senantiasa mengikuti dinamika perkembangan itu sendiri, begitu pula halnya dengan masyarakat dan bangsa Indonesia yang mau tidak mau bersinggungan dan terlibat langsung ${ }^{1}$.

Indonesia sebagai Negara kepulauan memiliki keanekaragaman seni budanya yang sangat kaya. Hal ini sejalan keanekaragaman etnik, suku bangsa dan agama yang secara keseluruhan merupakan potensi nasional yang perlu dilindungi. Kekanyaan seni dan budanya itu merupakan salah satu sumber dari karya intelektual yang dapat dan

\footnotetext{
${ }^{1}$ http://www.public.hki.go.id:HKI
} 
perlu dilindunggi. Kekayaan seni dan budanya itu merupakan salah satu sumber dari karya intelektual yang dapat dan perlu dilindunggi oleh undang-undang.

Salah satu perkembangan yang menonjol dan memperoleh perhatian seksama dalam masa sepuluh tahun terakhir dan kecenderungan yang masih berlangsung di masa yang akan datang adalah meluasnya globalisasi baik di bidang sosial, ekonomi, budanya maupun bidang- bidang kehidupan lainnya.

Dibidang perdagangan, terutama karena perkembangan teknologi informasi dan transportasi telah menjadikan kegiatan di sektor ini meningkat secara pesat dan bahkan telah menempatkan dunia sebagai pasar tunggal bersama. Dengan memperhatikan kenyataan dan kecenderunggan seperti itu maka menjadi hal yang dapat dipahami adanya tuntutan kebutuhan bagi pengaturan dalam rangka perlingungan hukum yang memadai, apalagi beberapa Negara semakin mengandalkan kegiatan ekonomi dan perdagangannya pada produk-produk yang hasilnya atas dasar kemampuan intelektualitas manusia seperti karya cipta di bidang ilmu pengetahuan, seni dan sastra ${ }^{2}$.

Adanya suatu undang-undang berarti adanya suatu pengaturan dan perlindungan ini adalah hal yang diharapkan bagi pelaku UU tersebut. Dilihat dari pasal demi pasal di dalam Undang-Undang No 28 Tahun 2014 tentang Hak Cipta jauh lebih sempurna dibandingkan UU yang telah direvisi dan juga adanya hukuman pidana kerugian minimal adalah merupakan pasal yang diharapkan dapat menjadikan momok bagi para pembajak. Namun pada kenyataannya pembajakan masih berlangsung. Perkembangan pembajakan saat ini terjadi karena penegakan Hukum yang dilakukan oleh aparat penegak Hukum dalam hal ini pihak kepolisian tidaklah dijalankan secara menyeluruh dan tuntas, atau dengan kata lain dijalankan dengan setengah hati sehingga tidak ada satu kasus pembajakan di bidang perfilman yang dapat dipakai sebagai yurisprudensi ${ }^{3}$.

UU No. 28 Tahun 2014 masih belum maksimal penerapannya, dalam masalah ini tidak bisa hanya melihat pada UU tapi amanah UU itu. Yang harus dilakukan oleh para penegak hukumlah yang belum dilaksanakan dengan baik. Hal ini dapat dilihat dari operasi penegakan Hukum pasca berlakunya UU No. 28 Tahun 2014 tentang Hak Cipta.

${ }^{2}$ Sentosa Sembriring, Prosedur Dan Tata Cara Memperoleh Hak Kekayaan Inteltual, Penerbit Yrama Widya, Bandung, 2002, hal 5

${ }^{3}$ Wihadi Wiyanto, Lampiran Makalah Penerapan Undang-Undang No. 19 Tahun 2002 Tentang Hak Cipta Dalam Rangka Memerangi Pembajakan. Hal 318 
Dari operasi yang telah dilakukan ini tidak ada kejelasan Hukum dan status dan pelaksanaan penegakan Hukum. Sampai saat ini pembajakan masih ada dan berlangsung dengan bebas. Hal ini merupakan situasi yang sangat kontradiktif apabila kita bandingkan dengan harapan dan gebrakan awal dan berlakunya UU No. 28 Tahun 2014. Jadi dengan kata lain bahwa setelah pihak aparat tidak lagi berkonsentrasi pada UU Hak Cipta dan penegakannya maka pelanggaran berlangsung kembali bahkan lebih berani ${ }^{4}$.

Muladi menyatakan bahwa penegakan Hukum pidana dalam kerangka sistem peradilan tidak dapat diharapkan sebgai satu-satunya sarana penanggulangan kejahatan yang efektif, mengingat kemungkinan besar adanya pelaku-pelaku tindak pidana yang berada di luar kerangka proses peradilan pidana ${ }^{5}$.

Donald R Taft dan Ralph W England, seperti dikutip Barda Nawawi Arief, menyatakan bahwa efektifitas Hukum pidana tidak dapat diukur secara akurat, Hukum hanya merupakan salah satu sarana kontrol sosial, kebiasaan keyakinan agama, dukungan dan pencelaan kelompok, penekanan dari kelompok kelompok interest dan pengaruh dari pendapat umumnya merupakan sarana yang lebih efisien dalam mengatur tingkah laku manusia dari pada sanksi Hukum ${ }^{6}$.

Penegakan Hukum atas Hak Cipta biasanya dilakukan oleh pemegang Hak Cipta dalam Hukum Perdata, namun ada pula sisi hukum pidana yang sanksi pidananya secara dikenakan kepada aktivitas pemalsuan yang serius namun kini semakin lazim pada perkara-perkara lain. Sanksi pidana atas pelanggaran Hak Cipta di Indonesia secara umum diancam dengan hukuman penjara paling singkat satu bulan dan paling lama tujuh tahun yang dapat disertai maupun tidak disertai denda sejumlah paling sedikit satu juta rupiah dan paling banyak lima milyar rupiah, sementara ciptaan atau barang yang merupakan hasil tindak pidanan hak cipta serta alat-alat yang digunakan untuk melakukan tindak pidana tersebut dirampas oleh Negara untuk dimusnahkan (UU 19/ 2002 bab XIII).

Dengan keluarnya Undang-Undang Hak Cipta No. 28 Tahun 2014 diharapkan pembajakan dapat diberantas. Namun setelah sekian bulan Back To Natur lagi.

\footnotetext{
${ }^{4}$ Ibid., hlm. 319.

${ }^{5}$ Muladi, Kapita Selekta Sistem Peradilan Pidana. (Semarang: Badan Penerbit Universitas Diponegoro, 1995) hlm. Vii.

${ }^{6}$ Barda Nawawi Arief, Beberapa Aspek Kebijakan Pengakan Dan Pembangunan Hukum Pidana (Bandung PT. Citra Aditya Bakti. 1998) hal 42
} 
Sebenarnya dengan adanya UU tersebut diharapkan pembajakan bisa ditanggulangi dan masyarakat bisa mulai mengerti. Pada saat itu telah dilakukan sosialisasi dengan mengadakan suatu acara mengenai publikasi UU No. 28 tahun 2014. dari situ ternyata diketahui banyak masyarakat yang sudah mengerti Undang-Undnag Hak Cipta. Kendati demikian pembajakan tetap saja berjalan. Kalau dilihat dan diamati dari tahun 80-an sampai sekarang bisa ditarik suatu garis besarnya. Pertama adalah masalah law enforcement, penegakan dan penanganan pelanggaran terhadap UU No. 8 tahun 1982 yaitu bahwa film tidak disensor saja tidak bias ditangani. Itu membuktikan adanya komponen dalam penegakan Hukum yang tidak berlajan dari kurun tahun 80-an sampai sekarang. Jadi sudah sekitar 20 tahunan masalah ini masih menjadi permasalahan saja sama seperti "Never Ending Story". Dalam hal ini diragukan juga keseriusan pihak aparat dalam menangani pembajakan $\mathrm{Hak} \mathrm{Cipta}^{7}$.

Dengan adanya korelasi antara pelanggaran hak cipta dengan ancaman pidana diharapkan mampu untuk mendorong upaya penanggulangan tindak pidanan dibidang HAKI khususnya Hak Cipta yang sedang marak-maraknya terjadi di Indonesia. Berkaitan dengan hal tersebut di dalam UU Hak Cipta menegaskan : "Barang siapa dengan sengaja menyiarkan, memamerkan, mengedarkan, atau menjual kepada umum suatu ciptaan atau barang hasil pelanggaran hak cipta atau Hak terkait, sebagaimana dimaksud dalam ayat (1) dipidana dengan pidana penjara paling lama 5 (lima) tahun dan atau denda paling banyak Rp 500.000.000,00 (lima ratus juta rupiah).

Dari ketentuan tersebut, maka dengan pembuktian yang cukup sederhana sebenarnya aparat penegak hukum sudah dapat melakukan tindakan terhadap praktek pembajakan, sehingga kerugian Negara yang diakibatkan oleh praktek pembajakan tersebut dapat dikurangi. Apabila hal tersebut juga dimaksudkan sebagai upaya untuk memberantas tindak pidana pembajakan nampaknya hal tersebut tidak akan berjalan efektif, praktek pembajakan yang merupakan pelanggaran terhadap UU Hak Cipta, sudah sepatutnya jika sanksi pidana yang dikenakannya di dasarkan pula pada UU Hak Cipta $^{8}$.

Pelanggaran HAKI khususnya Hak Cipta terjadi di Indonesia, setelah bangsa Indonesia diprotes oleh banyak Negara terutama Amerika Serikat atas pembajakan

7 Wihadi Wiyanto: Penerapan UU No. 19 tahun 2002 Tentang Hak Cipta Dalam Rangka Memerangi Pembajakan. Disampaikan pada Lokakarya Terbatas Masalah-Masalah Kepailitan dan Wawasan Hukum Bisnis Lainnya, Jakarta 10-11 Februari 2004

${ }^{8}$ Prosiding Simposium Nasional Haki, 18 Desember 2003. hlm 15. 
yang terjadi baik pada bidang Hak Cipta, Merek maupun paten. Negara-negara yang merasa dirugikan menempatkan Indonesia sebagai Priority Watch List sebagaimana juga yang diberlakukan pada Negara-negara Cina, Argentina dan Rusia.

Desakan-desakan dari Negara maju inilah yang telah menggugah pemerintah Indonesia untuk mulai berusaha terus menegakkan hukum dalam bidang HAKI, sehingga peringkatnya sudah agak turun tapi masih tetap menjadi incaran Negaranegara besar karena Indonesia dianggap gudangnya pembajakan.

Terakhir Indonesia dianggap sebagai pembajak program computer yang masuk dalam peringkat ketiga sedunia dalam kategori Negara yang tidak melaksanakan perlindungan HAKI diantaranya nomor satu Vietnam dan kedua Cina. HAKI mempunyai nilai ekonomis yang tinggi yang didalamnya tersangkut juga nilai moral yang harus dihormati. Tapi karena arena yang dimasuki adalah arena bisnis maka nilai moral yang berupa etika bisnis sudah diabaikan, sehingga persaingan ketat dalam era persaingan global membawa negara-negara untuk saling mencari pasar dengan caracara yang tidak etis. Tentu saja banyak kepentingan di dalamnya khususnya kepentingan ekonomis, maka tidak mustahil ada kepentingan kapitalisme global dibalik itu semua.

Setelah diberlakukannya UU No 28 tahun 2014, para pencipta pada bidang seni sastra dan ilmu pengetahuan mendapat perlindungan hukum sehingga tidak lagi mematikan kreatifitas para pengaragnya. Secara normatif apabila terjadi pembajakan maka sanksi yang diberlakukan sangat berat yaitu sanksi pidana penjara tujuh tahun dan/atau denda paling banyak Rp 5.000.000.000,00 (lima milyar rupiah), terdapat dalam pasal 72 ayat 1, sedang pada ayat (3) nya menyangkut program computer dipidana penjara paling lama 5 (lima) tahun dan/atau denda paling banyak Rp 500.000.000,00 (lima ratus juta rupiah). Apakah sanksi pidana yang dijatuhkan sedemikian berat akan membawa implikasi positif pada dunia bisnis? diberlakukannya Undang- Undang No. 28 tahun 2014 ini membawa harapan yang sangat besar, sehingga para pebisnis akan dapat mengeksploitas hak ekonomis atas ciptaannya semaksimal mungkin dalam rangka mencapai tujuan bisnis sesuai yang diinginkan.

Berdasarkan latar belakang di atas, maka dirumuskan masalah sebagai berikut :

1. Bagaimanakah pengaturan Perlindungan Hak Cipta di Indonesia? 
2. Bagaimana ketentuan pidana terhadap pelanggaran Hak Cipta sebagai upaya perlindungan hukum bagi Hak atas Kekayaan Intelektual berdasarkan ketentuan hukum positif yang ada?

\section{METODE}

Penelitian ini menggunakan metode pendekatan Yuridis Normatif, yakni penelitian yang menitikberatkan pembahasan pada data-data sekunder berupa bahanbahan hukum, baik primer, sekunder maupun tersier, yang didukung data primer. Pendekatan yuridis digunakan untuk meneliti ketentuan penegakan hukum atas hak kekayaan intelektual regim Hak Cipta.

Spesifikasi penelitian ini adalah deskriptif analitis, yaitu penelitian yang bertujuan menggambarkan mengenai fakta-fakta disertai analisis yang akurat mengenai peraturan perundang-undangan menganai hak cipta dalam menegakan pelanggaran terhadap hak simpta.

Teknik pengumpulan data dilakukan melalui Penelitian kepustakaan Penelitian kepustakaan dilakukan untuk memperoleh bahan-bahan hukum baik primer, sekunder, maupun tersier. ${ }^{9}$ Bahan hukum primer adalah bahan-bahan yang berasal dari peraturan perundang-undangan nasional, khusunya difokuskan pada pengkajian peraturan hukum pidana dibidang hak Cipta. Bahan hukum sekunder yakni terdiri dari doktrin-doktrin, pendapat para ahli yang dapat terlihat dalam buku-buku hukum dan makalah-makalah yang ditulis oleh para ahli, karangan berbagai panitia pembentukan hukum, hasil penelitian hukum, RUU dan lain-lain yang dapat memberikan penjelasan mengenai bahan hukum primer. Di samping itu dikaji pula bahan hukum tersier, yakni berupa pendapat-pendapat atau opini masyarakat yang ada di dalam majalah-majalah dan surat kabar, kamus, ensiklospedi, yang dapat memberikan petujuk maupun penjelasan terhadap bahan hukum primer maupun sekunder

Teknis Analisis data yang digunakan dalam penelitian ini adalah deskriptif preskiptif, yakni pemaparan dan penggambaran penegakan peraturan perundangundangan di bidang hak kekayaan intelektual regim hak cipta.

${ }^{9}$ Sunaryati Hartono, Penelitian Hukum di Indonesia Pada Akhir Abad ke-20, Alumni, Bandung, 1994, hlm. 134. 


\section{PEMBAHASAN}

\subsection{Pengaturan Hak Atas Kekayaan Intelektual Regim Hak Cipta}

Hak Kekayaan Intelektual atau HKI, secara substantif dapat diartikan sebagai Hak atas kekayaan yang timbul atau lahir karena kemampuan intelektual manusia. Hak atas Kekayaan Intelektual atau Intelektual Property Right dikelompokan dalam hak yang dimiliki secara perorangan yang tidak dalam wujud kebendaan. Hak tersebut secara khusus diberikan kapada pemilik dan pemegang hak dalam hal mengumumkan, memperbanyak dan mengedarkannya, atau memberikan ijin kepada orang lain atas ciptaannya tersebut dengan batasan waktu tertentu. Dapat disimpulkan juga bahwa hak cipta sebagai hak eksklusif (exclusive right) merupakan subyek hukum yang bersifat immaterial yang melindungai hubungan kepentingan antara pencipta dengan keasliannya ciptaannya.

Keberadaan Undang-undang Hak Cipta memang diperuntukkan khusus untuk melindungi hak bagi mereka yang telah menghasilkan karya-karya yang berasal dari pcngungkapan (ekspresi) intelaktualitas (intangible), dan bukannya yang bersifat kebendaan (tangible), apabila yang belum berwujud apa-apa seperti ide-ide informasi dan lain sebagainya ${ }^{10}$.

Hak cipta adalah hak eksekusi yang diberikan oleh pemerintah) untuk mengatur penggunaan hasil penuangan gagasan atau informasi tertentu. Pada dasarnya "hak cipta merupakan hak untuk menyalin suatu ciptaan”. Hak Cipta dapat juga memungkinakn pemegang hak tersebut untuk membatasi penggandaan tidak sah atas suatu ciptaan. Pada umumnya pula hak cipta memiliki masa berlaku tertentu yang terbatas ${ }^{11}$.

Hak cipta berlaku pada berbgai jenis karya seni atau karya ciptaan ciptaan tersebut dapat mencakup puisi, drama, serta kaya tulis lainnya, film karya koreografis (tari, balet) dan sebagainya) komposisi musik, rekaman suara lukisan, gambar, patung, foto perangkat lunak computer, siaran radio dan televisi dan (dalam yurisdiksi tertentu) desain industri.

Hak cipta merupakan salah satu jenis hak kekayaan intelektual. Namun hak cipta membedakan secara mencolok dari hak kekayaan intelektual lainnya (seperti paten yang memberikan hak monopoli untuk melakukan sesuatu, melainkan hak untuk

10 Etty Susilowati, Bunga Rampai Hak Kekayaan Intelektual. Semarang : 2007. Program Magister Ilmu Hukum Universitas Diponegoro.

${ }^{11} \mathrm{http} / / / \mathrm{www}$.en.wikipedia.org/wiki/hakcipta 
mencegah orang lain yang melakukannya Hukum yang mengatur hak cipta biasanya hanya mencakup ciptaan yang berupa perwujudan suatu gagasan dan tidak mencaup gagasan umum, konsep, fakta, gaya atau teknik yang mungkin terwujud dan terwakili didalam ciptaan tersebtu sebgai contoh, hak cipta yang berkaitan dengan tokoh kartun miili tikus melarang pihak yang tidak berhak menyebarkan salinan kartun tersebut atau menciptakan karya yang meniru tokoh tikus tertentu ciptaan walt Disney tersebut namun, tidak melarang penciptaan atau karya seni lain mengenai tokoh tikus secara umum

Di Indonesia masalah hak cipta diatur dalam undang-undang hak cipta, yaitu yang berlaku sat ini, undang-undang nomor 28 tahun 2014 tentang Hak Cipta. Didalam undang-undang tersebut pengertian hak cipta adalah "hak ekslusif bagi penciptanya atau penerima ha kuntuk mengumumkan atau memperbanyak ciptaanya atau memberikan ujin untuk itu dengan tidak mengurangi batasan-batasan menurut peraturan perundang-undangan yang berlaku (pasal 1 butur 1).

Undang-undang No. 19 Tahun 2002 tentang Hak Cipta telah diubah dengan Undang-Undang No. 28 tahun 2014. Perkembangan undang-undang tentang Hak Cipta berkaitan dengan isu penegakan (inforcement) yang tidak saja menjadi isu nasional, tetapi juga regional dan isu internasional. Hak cipta tidak lepas sebagai bagian dari hak kekayaan intelektual yang terdiri dari perlindungan seni, sastra ilmu pengetahuan dan hak-hak terkait Merek, Paten, Desain industri, desain tata Letak Sirkuit Terpadu, dan Rahasia Dagang. Serta perlindungan dan varietas tanaman. Ada pengembangan Haki yang tidak tercakup dalam undang-undang tentang Hak Cipta yaitu genetic resource traditional knowledge \& for klor (GRTKF). Untuk faktor perlindungan berada dibawah undang-undang Hak Cipta ${ }^{12}$.

Latar belakang perlindungan hak cipta adalah karena kita memiliki budaya yang sangat tinggi dan beraneka ragam sehingga diharapkan terwujudnya perkembangan terhadap produk-produk hak cipta sehingga diperlukan perlindungan atas hak cipta tersebut. Selain itu juga karena Indonesia sebagai salah satu anggota dari WTO, TRIPS, dan WTC. Perlindungan hak cipta diatas berdasarkan ketentuan bern convention. Akan tetapi dipisahkannya hak cipta dengan hak terkait, maka hak terkait tidak memiliki perlindungan secara international, karena Indonesia belum menjadi anggota dari Reom convention dan the WIPO performance phonograms threaty (WPPS) sehingga kalu

${ }^{12}$ Prosiding Haki, Jakarta 10-11 Februari 2004. hal 285 
broadcasting Indonesia di copy oleh Malaysia, Singapura dan Negara anggota roem convention dan WPPT lainnya maka kita tidak bisa mengklaim.

Pemberian sanksi yang tinggi terhadap pelanggaran hak cipta diharapkan dapat mendorong kreativitas. Dalam rangka memberantas pembajakan departemen kehakiman mengadakan kerjasama kira-kira dengan 18 assosiasi dibidang hak cipta yang bertujuan agar dapat mendorong kreativitas dengan menghormati karya orang lain serta untuk meningkatkan system usaha di bidang hak cipta.

Pentingnya perlindungan hak cipta adalah kepastian hukum pada masyarakat pencipta sehingga akan mengundang investor untuk investasi dananya di Indonesia. Hambatan dalam bidang hak cipta ada pada sifat perlindungan hak cipta adalah otomatis. Bagi pencipta tidak diwajibkan untuk melakukan pendaftaran, pendaftaran dapat mendukung adanya kepastian hukum bagi para pencipta. Lingkup perlindungan hak cipta selain karya seni, sastra dan Ilmu pengetahuan adalah folklore. Folklore adalah hak milik Negara. Di dunia internasional, folklore sedang diperdebatkan apakah masuk ke lingkup Hak Atas Kekayaan Intelektual (HAKI) atau bukan. Karena para anthropolog Indonesia menyatakan bahwa folklore adalah termasuk tradisional knowledge seperti tari-tarian Jawa, Bali dsb. Akan tetapi menurut ketentuan internasional, folklore harus diatur dalam undang-undang hak cipta, sedangkan folklore adalah sesuatu yang berkaitan denga karya sastra dan budaya, sehingga timbul perdebatan yang besat antara ahli folklore dengan ahli anthropolog.

Menurut Satjipto Rahardjo, tidak secara otomatis munculnya suatu kepastian hukum saat lahirnya produk Undang-Undang. Ternyata peraturan bukan satu-satunya factor menyebabkan munculnya kepastian hukum, melainkan factor yang cukup adalah perilaku dari masyarakat itu sendiri. Tidak dapat dipungkiri bahwa minimnya daya beli masyarakat terhadap bentuk asli memang merupakan permasalahan dalam memberantas berbagai pelanggaran HKI di Indonesia ${ }^{13}$. Selain masalah tersebut, menurut Ansori Sinungan selaku Direktur Hak Cipta HKI dalam penegakan hukum HKI di Indonesia terdapat dilemma, yang dapat dilihat dari beberapa aspek. Pertama, aspek budaya dimana masyarakat cenderung belum merasa bersalah menggunakan barang bajakan. Kedua aspek social, dimana seharusnya penegak hukum harus dilakukan tanpa pandang bulu. Dan ketiga, aspek hukum dimana masih terdapat perbedaan persepsi mengenai hukum HKI. Dan para penegak hukum dan masyarakat.

${ }^{13}$ Satjipto Raharjo, Biarkan Hukum Mengalir, Jakarta : Penerbit Buku. Kompas, 2007 
Menurut R. Abdussalam, berbagai pelanggaran norma atau kaidah yang sering terjadi dimasyarakat adalah akibat ${ }^{14}$ :

1. Sikap lunak terhadap pelanggar hukum yang dianggap kecil atau ringan

2. Tingkah laku petugas kepolisian yang mengurangi cipta baik tentang penegakan hukum

3. Pelanggaran hukum yang dibiarkan dan dalam waktu singkat diikuti oleh jumlah orang yang lebih banyak dan tidak dipidana.

4. Tingkah laku petugas kepolisian yang merusak citra kesatuannya seperti pungutan luar, perlakuan kasar, tidak memberikan pelayanan yang baik, sehingga menimbulkan skeptis dalam masyarakat terhadap segala usaha yang baik dari penegak hukum atau petugas kepolisian.

Perhatian dunia internasional terhadap masalah hak cipta telah melahirkan beberapa konvensi internasional di bidang hak cipta. Sejak pertama kali disepakatipemebrian perlindungan terhadap karya sasatra dan karya seni dalam Berne Convention 1886, telah mengilhanai lahirnya beberapa konvensi susulan yang. merupakan kesepakatan antar negara" dalam mengatur masalah hak cipta secara lebih spesifik, termasuk di dalam pemberian perhatian terhadap karya cipta yang dihasilkan karena perkembangan teknologi, rnisalnya karya cipta di bidang Phonograms, Distribution programme carrying signals transmitted by Satelite ${ }^{15}$.

Beberapa kesepakatan bersama antar negara yang mengatur masalah hak cipta antara lain:

a. Bem Convention for the Protection af Uteraray 2nd Artistic Works 1886;

b. Universal Copyright Conventian 1955;

c. Rome Canventian far tile Pratection af Performers, Producers of Phonograms and Broadcasting Organizations 1961;

d. WIPO Copyright Treaty (WC7) 1996;

e. WIPO Performances and Phanograms Treaty(WPP7) 1996:

f. Brussels Convention relaling to the Oisirioution of Prograrnme carrying signals transmitted by Satelite 1974.

${ }^{14}$ Abdussalam, Hukum Kepolisian Sebagai Hokum Positif Dalam Disiplin Hukum, (Restu Agung, 2007).

${ }^{15}$ Budi Santoso, Materi Hak cipta, disampaikan pada pelatihan PRE-SERTIFIKASI HKI KLINIK HARI Fakultas Hukum Universitas Diponegoro, Semarang 2008. 
g. Convention for tile Protection of Producers of Phonograms Against Unauthorized Duplication of Their Phonograms 1971

h. Treah on the International registration of Audiovisual Works (Film Register Treaty) 1991.

Selain itu, terdapat pula konvensi internasional yang mengatur juga masalah hak cipta sebagai bagian dari hak milik intelektual pada umumnya, yaitu :

a. Trips (Marakesh Agreement 15-04-1994);

b. OAPI (Bangui Agreement Revising Extracts 24-02-1999);

c. OAPI (Bangui Agreement 02-03-1977;

d. NAFTA (Intellectual Property Excerpts 08-12-1993); ${ }^{16}$

Dari rangkaian kesepakatan bersarna di bidang hak cipta maka Bern convention merupakan konvensi tertua yang mengatur masalah hak cipta. Konvensi Bern di tandatangani di Bern,lbu kota Swidzerland,pada tanggal 9 September 1886 oleh sepuluh negara peserta asli (Belgium, France, germany, Great Britain, Haiti, ltaly, Liberia, Spain, Swidzerland, Tunisia) dan tujuh negara yang menjadi peserta dengan cara aksesi ( Denmark, Japan, Luxemburg, Monaco, Montenegro, Norway, Sweden ).

Sejak zaman Belanda Hak Cipta diatur pada Auteurswet Tahun 1912 Stb. No. 600. aturan tentang hak cipta ini tampaknya sudah tidak sesuai lagi dengan kebutuhan masyarakat serta cita-cita Hukum nasional, sehingga auteurswet ini disebut. Untuk pertama kalinya setelah Indonesia merdeka hak cipta diatur pada Undang-Undang No. 6 Tahun 1982, yang diubah UUHC No. 7 tahun 1987, selajutnya diubah kembali dengan UUHC No. 12 Tahun 1997 tentang Hak Cipta terakhir kali diundangkan UUHC No 19 Tahun 2002. Undang-Undang ini dikeluarkan untuk merealisasi amanah Garis Besar Haluan Negara (GBHN) dalam rangka pembangunan dibidang Hukum, dimaksudkan untuk mendorong dan melindungi pencipta dan hasil karya ciptaanya diharapkan penyebarluasan hasil kebudayaan dibidang karya ilmu seni dan sastra dapat dilindungi secara yuridis yang pada gilirannya dapat mempercepat proses pertumbuhan kecerdasan kehidupan bangsa ${ }^{17}$.

Sejak Indonesia menyataka berdaulat penuh pada 17 Agustus 1945 diikuti dengan dibuatnya UUD 45 tanggal 18 Agustus maka berdasarkan Pasal II aturan

${ }^{16} \mathrm{http}: / / \mathrm{www}$. wipo.org

17 Muhammad Djumhana dan R. Djubaedillah, Hak Milik Intelektual (Sejarah, Teori dan Praktiknya di Indonesia) bandung, citra aditya Bhakti, 1997. 
peralihan UUD 45 maka semua peraturan perundangan peninggalan jaman kolonial Belanda tetap langsung berlaku sepanjang belum dibuat yang baru dan tidak bertentangan dengan UUD 45. Berdasarkan ketentuan tersebut maka khusus yang berkaitan dengan pengaturan hak cipta diberlakukan Auteurswef 1912 peninggalan kolonial belanda. Tiga puluh tahun kemudian, tepatnya tahun 1982 baru Pemerintah RI dapat membuat UU hak cipta nasional yang dituangkan dalam UU No. 6 tahun 1982 tentang hak cipta ini banyak mengalami perubahan serta penambahan peraturan pelaksana, $\operatorname{sbb}^{18}$ :

a. UU No .6 tahun 1982 tentang Hak Cipta:

b. UU No .7 tahun 1987 tentang Perubahan UU No. 6 tahun 1982 tentang Hak Cipta;

c. UU No.12 tahun 1997 tentang Perubahan UU No .6 tahun 1982 sebagaimana diubah dengan UU No. 7 tahun 1987 tentang hak Cipta;

d. UU No.19 tahun 2002 tentang hak Cipta yang menyatakan mencabut UU lama tentang hak cipta No. 12 Tahun 1997

e. $\quad$ UU No. 19 Tahun 2002 selanjutnya diganti dengan UU No. 28 Tahun 2014.

f. UU No.4 tahun 1990 tentang Wajib Serah Simpan Karya Cetak dan Karya rekam.

Selain diatur dalam UU maka sebagai kelengkapan pengaturan hak cipta juga diatur dalam beberapa peraturan pelaksanaan, yaitu:

a. $\quad$ PP NO.14 tahun 1986 Jo PP NO.7 tahun 1989 tentang Dewan hak Cipta;

b. PP NO.1 tahun 1989 tentang penerjemahanhan dan perbanyakan ciptaan untuk kepentingan pendidikan, ilmu pengetahuan.penelitian dan pengembangan".

c. Keppres RI NO.18 tahun 199.7 tentang pengesahan Berne Convention for the Protection of Literaray and Artistic works.

d. Keppres RI NO.17 tahun 1988 tentang Pengesahan persetujuan mengenai perlindungan Hukum secara timbal balik terhadap hak Cipta atas Rekaman Suara antara RI dengan Masyarakat Eropa:

e. Keppres RI NO.25 tahun 1989 tentang Pengesahan Persetujuan mengenai Perlidungan Hukum secara timbal balik terhadap hak Cipta anatar RI dengan Amerika Serikat;

f. $\quad$ Keppres RI NO.38 tahun 1993 tentang pengesahan persetujuan

\footnotetext{
${ }^{18}$ Budi santoso, Materi Hak Cipta, Opcit. Hlm. 41.
} 
g. Perlindungan Hukum secara timbai balik terhadap hak cipta antara Rl dengan Australia:

h. Keppres RI NO.56 tahun 1994 tentang pengesahan persetujuan mengenai perlindungan terhadap Hak Cipta antara RI dengan lnggris:

i. Peraturtan menteri Kehakiman Rl NO.M.01-HC.03.01 tahun 1987 tentang pendaftaran Ciptaan:

j. Keputusan menteri kehakiman R1,NO.M.04.PW.07.03 tahun 1988 tentang Penyidikan hak cipta;

k. Surat Edaran menteri kehakiman RI NO.M.01.PW 07.03 tahun 1990 tentang kewenangan menyidik Tindak Pidana Hak Cipta;

1. Surat Edaran menteri kehakiman RI NO.M.02.I:C.03.01 tahun 1991 tentang Kewajiban melampirkan NPWP dalam permohonan pendaftaran ciptaan dan pencatatan pemindahan hak cipta terdaftar.

\subsection{Klasifikasi Hak Cipta menurut UU No 19 tahun 2002 tentang Hak Cipta}

Menurut ketentuan Pasal 11 ayat UUHC, ciptaan yang dilindungi oleh UUHC adalah ciptaan dalam bidang ilmu pengetahuan, seni dan sastra yang meliputi bebagai jenis karya berikut ini ${ }^{19}$ :

a. Buku, program komputer, Famflet, susunan perwajahan karya tulis yang diterbitkan, dan semua hasil karya tulis lainnya;

b. Ceramah, kuliah, pidato, clan eiptaan lainnya yang diwujudkan dengan cara diucapkan;

c. Alat peraga yang dibuat untuk kepentingan pendidikan dan ilmu pengetahuan;

Ciptaan lagu atau musik dengan atau tanpa teks, termasuk karawitan, dan rekaman suara;

d. Drama, tari (koregrati), pewayangan, pantomin;

e. Karya pertunjukan;

f. Karya siaran;

g. Seni rupa dalam bentuk seperti seni lukis, gambar, seni ukir, seni kaligrali.

h. seni pabat, seni patung, kolase, seni terapan yang berupa seni kerajinan tangan;

i. Arsitektur;

19 Rachmadi Usman : Hukum Hal Atas Kekayaan Intelektual (Perlindungan dan Dimensi hukumnya di Indonesia). Bandung PT: Alumni 2003 
j. Peta;

k. Seni batik;

1. Fotografi;

m. Sinematografi;

n. Terjemahan, tafsiran, saduran, bunga rampai dan karya lainnya dari hasil pengalihwujudan.

Dasar Filosofi berlakunya hak cipta adalah sesuai dengan konsepsi hak milik yang bersifat immaterial yang merupakan hak kebendaan. Hak kebendaan yang mempunyai sifat droit de suit, senantiasa mengikuti dimana benda tersebut berada, sehingga pemilik boleh melakukan tindakan Hukum apa saja terhadap haknya. Adanya batasan waktu pemilikan hak cipta dalam jangka waktu selama hidup ditambah 50 tabun, diharapkan hak cipta tidak tertahan lama pada tangan seseorang pencipta sebagai pemiliknya. Sehingga setelah si pencipta meninggal dan ditambah dengan 50 tahun, selanjutnya haknya dapat dinikmati oleh masyarakat lusa secara bebas sebagai milik umum (Public domain), artinya masyarakat boleh mengumumkan atau mernperbanyak tanpa harus minta izin kepada si pencipta atau si pemengan hak dan tidak dianggap sebagai pelanggaran hak cipta. Pembatasan jangka waktu hak cipta yang tercantum pada UUHC No. 28 tahun 2014, dikenal juga pada aturan Belanda yaitu Auterswet 1912. Ketentuan auterswet ini merupakan pengambilalihan dari ketentuan Internasional Konvensi Bern.

Pembatasan hak cipta mempunyai makna supaya hak pencipta sebagai pemilik suatu ciptaan senantiasa benar-benar dihormati sebagai hak individu, dengan jangka waktu yang relative panjang akan tercipta keseimbangan antara kepentingan individu dan masyarakat yang dikenal dengan konsepsi hak milik yang berfungsi sosial. Walaupun demikian dalam praktek ternyata batasan kepemilikan hak cipta ini justru sering menguntungkan pihak lain yaitu pihak prosedur dalam hal karya lagu serta karya seni lainnya dan pada pihak penerbit dalam hal karya cipta berupa buku. Hal ini tidak terlepas dari hak cipta yang mengandung sifat komersial, yaitu ada unsur ekonomis dalam rangka mencari keuntungan.

Sebagian dari institusi hukum mengenai Hak Cipta (copy right) bertujuan melindungi karya seni yang diciptakan oleh para seniman. Dalam konteks hukum karya seni merupakan bagian dari HAKI dan HAKI pun merupakan suatu hak yang timbul akibat adanya tindakan kreatif manusia yang menghasilkan karya-karya inovatif yang 
dapat diterapkan dalam kehidupan manusia. Hukum memberikan perlindungan terhadap seniman dan karyanya yang lahir dari sebuah proses penciptaan daya itelektual, karsa dan rasa sang seniman. Di Indonesia pengaturan perlindungan tersebut di tuangkan dalam Undang-Undang No. 28 tahun 2014 tentangt Hak Cipta atas perintah pasal 105 Undang-Undang tersebut.

\subsection{Penegakan Hukum Pidana Terhadap Pelanggaran Hak Cipta}

Sebagian dari institusi hukum mengenai Hak Cipta (copy right) bertujuan melindungi karya seni yang diciptakan oleh para seniman. Dalam konteks hukum karya seni merupakan bagian dari HAKI dan HAKI pun merupakan suatu hak yang timbul akibat adanya tindakan kreatif manusia yang menghasilkan karya-karya inovatif yang dapat diterapkan dalam kehidupan manusia. Hukum memberikan perlindungan terhadap seniman dan karyanya yang lahir dari sebuah proses penciptaan daya itelektual, karsa dan rasa sang seniman. Di Indonesia pengaturan perlindungan tersebut di tuangkan dalam Undang-Undang No. 28 tahun 2014 tentang Hak Cipta Pasal 78 Undang-Undang tersebut. Pasal 2 Undang-Undang tersebut mengatakan bahwa Hak Cipta merupakan hak eksklusif bagi pencipta dan pemegang hak cipta. Artinya, bahwa hak tersebut semata-mata diperuntukkan bagi pemegangnya sehingga tidak ada pihakpihak lain yang boleh memanfaatkan hak tersebut tanpa izin pemegangnya. Jadi, sebagai suatu hak eksklusif HAKI tidak dapat dapat diganggu gugat. Hal ini sejalan dengan prinsip droit inviolable et sacre dari hak melik itu sendiri. Hak eksklusif itu sendiri tidak saja tertuju padamasyarakat. Oleh karena itu, tujuan hukum HAKI adalah menyalurkan kreativitas individu untuk kemanfaatan manusia secara luas. Namun, kenyataannya di Indonesia kreasi para seniman secara hukum belum dihargai sebagaimana mestinya oleh masyarakat maupun kalangan seniman itu sendiri.

Hal tersebut dapat disebabkan oleh berbagai hal, antara lain HAKI sebagai sebuah institusi hukum dirasakan belum mampu melindungi kepentingan hukum para seniman. Atau boleh jadi seniman itu merasa tidak "membutuhkan" perlindungan HAKI. Dalam hal ini tampaknya sang seniman lebih memandang keberadaan HAKI hanya dari aspek kepentingan moralitas dirinya ketimbang keuntungan ekonomis. Meskipun Undang-Undang No. 28 Tahun 2014 melindungi kedua kepentingan tersebut sebagaimana tertera dalam bagian ketujuh mengenai hak moral pencipta. Pasal 24 ayat 
2 menyatakan bahwa suatu hak cipta tidak boleh diubah walaupun hak ciptanya telah diserahkan kepada pihak lain, kecuali dengan persetujuan pencipta atau dengan persetujuan ahli warisnya dalam hal pencipta telah meninggal dunia.

Pasal ini dengan jelas memperlihatkan bahwa aspek ekonomi dan aspek moral dari hak cipta dilindungi oleh hukum. Contohnya sebuah lirik lagu yan telah dijual ke perusahaan rekaman oleh penciptanya, tidak boleh nama pencipta lirik lagu tersebut dihapuskan beghitu saja meskipun ketika karya tersebut dipublikasikan. Hal ini merupakan kemajuan yang berarti dalam Undang- Undang Hak Cipta kita saat ini. Karena Undang-Undang tersebut mengakui dimensi moral dari karya itu lahir bukan hanya atas dasar kepentingan ekonomi tetapi merupakan ekspresi dari eksistensi sang seniman sebagai manusia yang dilindungi hak asasi manusianya (HAM) secara Universitas sebagai seperangkat hak yang melekat pada hakikat keberadaan manusia sebagai mahluk tuhan. Pelanggaran terhadap hak moral sang seniman berarti pelanggaran terhadap HAM sebagaimana diatas dalam Undang-Undang No. 39 tahun 1999 tentang hak asasi manusia ${ }^{20}$.

Diadakannya undang-undang atau aturan hukum terhadap suatu masalah, bisaanya disebabkan adanya hal-hal yang menimbulkan kerugian moral maupun material terhadap suatu pihak. Tujuan pengaturan berupa perlindungan bagi masyarakat atau sebuah komunitas dan sanksi terhadap kegiatan apa pun yang menyebabkan timbulnya kerugian itu, untuk memberikan terapi hukum serta pengajaran bagi para pelanggar aturan serta untuk meminimalisir kegiatan-kegiatan yang dapat merugikan orang lain tersebut.

Pelanggaran hak cipta atau karya buku sudah terjadi sejak berlakunya Auteurswet 1912 dan makin meningkat hingga berlakunya Undang-Undang Hak Cipta 1982. Auteurswet pada hakikatnya tidak mempunyai dampak terhadap perlindungan hak cipta. Mengingat masyarakat Indonesia pada waktu itu, yaitu masa berlakunya Auteurswet tersebut belum cukup mencapai tingkat pemahaman mengenai arti dan kegunaan hak cipta. Terdapat hambatan cultural atas perlindungan hak cipta pada masa itu. Perlindungan Hak Cipta secara individual pada hakikatnya merupakan hal yang tidak dikenal di Indonesia.

Suatu ciptaan oleh masyarakat dianggap secara tradisional sebagai milik bersama. Tumbuhnya kesadaran bahwa ciptaan itu perlu perlindungan hukum setelah

\footnotetext{
${ }^{20}$ http: //wiki.org/haki/.
} 
dihadapinya bahwa ciptaan itu mempunyai nilai ekonomi. Adapun dalam pandangan tradisional segi nilai moral hak cipta lebih menonjol daripada nilai ekonomisnya.

Baru setelah menonjol nilai ekonomi dari hak cipta, terjadilah pelanggaran terhadap Hak Cipta, terutama dalam bentuk tindak pidana pembajakan lagu atau musik, buku dan penerbitan, film dan rekaman video serta komputer. Pelanggaran terhadap Hak Cipta ini disebabkan oleh sikap dan keinginan sebagai (anggota) masyarakat kita untuk memperoleh keutungan dagang dengan cara mudah. Sebagai akibatnya bukan saja merugikan pencipta atau pemegang Hak Cipta, tetapi juga merugikan perekonomian pada umumnya.

Undang-Undang No 28 Tahun 2014, selanjutnya ditulis UUHC 2014 telah menyediakan dua sarana hukum, yang dapat dipergunakan sekaligus untuk menindak pelaku pelanggaran terhadap hak cipta, yakni sarana hukum pidana dan hukum perdata. Pelanggaran terhadap hak cipta dapat dituntut secara pidana dan perdata sekaligus sebagaimana disebutkan Pasal $105^{21}$.

Berdasarkan Pasal 96 dan Pasal 112 sampai dengan Pasal 119 UUHC 2014 , pelaku pelanggaran terhadap hak cipta, selain dituntut secara perdata, juga dapat dituntut secara pidana. Demikian UUHC 2014 juga telah menyediakan dua sarana hukum, yang dapat dipergunakan untuk menindak pelaku pelanggaran terhadap Hak Cipta, yaitu melalui sarana instrumen hukum pidana dan hukum perdata, bahkan, dalam UUHC 2014, penyelesaian sengketa di bidang hak cipta dapat dilakukan di luar pengadilan melalui arbitrase atau alternatif penyelesaian sengketa lainnya sebagaimana dinyatakab Pasal 95 ayat (1).

Pengajuan tuntutan pelanggaran atas hak cipta dapat juga dilakukan secara pidana. UUHC telah merumuskan perbuatan-perbuatan yang dikategorikan sebagai tindak pidana hak cipta. Semula tindak pidana hak cipta ini merupakan delik, tetapi kemudian diubah menjadi delik aduan Pasal 120. Dengan menjadi delik aduan, penindakannya semata-mata didasarkan pada adanya pengaduan dari pencipta atau pemegang hak cipta yang merasa dirugikan, sehingga penegakan hukumnya menjadi kurang efektif. Selain itu, ancaman pidananya pun terlalu ringan dan kurang mampu menjadi penangkal terhadap pelanggaran hak cipta, sehingga ancaman pidananya pun

${ }^{21}$ Endang Purwaningsih, ibid, hlm. 158. 
diperberat guna lebih melindungi iasapemegang hak cipta dan sekaligus memungkinkan dilakukan penahanan sebagaimana diatur dalam KUHAP ${ }^{22}$.

UUHC 2014 memuat secara rinci jenis-jenis Tindak Pidana Hak Cipta yang jelas dalam lingkup ilmu pengetahuan, kesenian dan kesusasteraan. UUHC 2014 merumuskan ancaman pidana dan denda secara minimal di samping secara maksimal. Kemudian mengadakan ketentuan baru mengenai ancaman pidana atas pelanggaran Hak Terkait dan terhadap perbanyakan penggunaan Program Komputer untuk kepentingan komersial secara tidak sah dan melawan hukum. Beberapa ketentuan tindak pidana diamana pelanggaran terhadap hak cipta diancaman dengan hukuman pidana, dapat terlihat pada pasal-pasal sebagai berikut :

1. Pelanggaran hak ekonomi terhadap Pasal ayat (3) dan/atau Pasal 52 untuk penggunaan secara komersial, ancamannnya ditetapkan didalam Pasal 112.

2. Pelanggaran hak ekonomi terhadap Pasal 9 ayat (1) huruf i untuk penggunaan secara komersial ditetapkan ancamannya didalam Pasal 113 ayat (1).

3. Pelanggaran hak ekonomi terhadap Pasal 9 ayat (1) huruf c, hurud d, huruf $\mathrm{f}$ dan/atau huruf g untuk penggunaan secara komersial ditetapkan ancamannya didalam Pasal 113 ayat (2).

4. Pelanggaran terhadap hak ekonomi Pasal 9 ayat (1) huruf a, hurud b, huruf e dan/atau huruf g untuk penggunaan secara komersial ditetapkan ancamannya didalam Pasal 113 ayat (3).

5. Pelanggaran dengan kategori pembajakan terhadap Pasal 9 ayat (1) huruf a, hurud $b$, huruf e dan/atau huruf $g$ ditetapkan ancamannya didalam Pasal 113 ayat (4).

6. Pelanggaran hak ekonomi terhadap Pasal 23 ayat (2) huruf e untuk penggunaan komersial ditetapkan ancamannya didalam Pasal 116 ayat (1).

7. Pelanggaran terhadap hak ekonomi Pasal 23 ayat (2) huruf a, hurud b dan/atau huruf $f$ untuk penggunaan secara komersial ditetapkan ancamannya didalam Pasal 116 ayat (2).

8. Pelanggaran terhadap hak ekonomi Pasal 23 ayat (2) huruf c dan/atau huruf d untuk penggunaan secara komersial ditetapkan ancamannya didalam Pasal 116 ayat (3).

${ }^{22}$ Ibid., hlm. 165 
9. Pelanggaran dengan kategori pembajakan terhadap Pasal 23 ayat (2) huruf c dan/atau huruf d untuk penggunaan secara komersial ditetapkan ancamannya didalam Pasal 116 ayat (4).

10. Pelanggaran hak ekonomi terhadap Pasal 24 ayat (2) huruf c untuk penggunaan secara komersial ditetapkan ancamannya didalam Pasal 117 ayat (1).

11. Pelanggaran terhadap hak ekonomi Pasal 24 ayat (2) huruf a, huruf b, dan/atau huruf d untuk penggunaan secara komersial ditetapkan ancamannya didalam Pasal 117 ayat (2).

12. Pelanggaran dengan kategori pembajakan terhadap Pasal 24 ayat (2) huruf a, huruf $\mathrm{b}$ dan/atau huruf $\mathrm{d}$ untuk penggunaan secara komersial ditetapkan ancamannya didalam Pasal 117 ayat (3).

13. Pelanggaran terhadap hak ekonomi Pasal 25 ayat (2) huruf a, huruf b, huruf c, dan/atau huruf $d$ untuk penggunaan secara komersial ditetapkan ancamannya didalam Pasal 118 ayat (1).

14. Pelanggaran terhadap hak ekonomi Pasal 25 ayat (2) huruf d dengan maksud pembajakan ditetapkan ancamannya didalam Pasal 118 ayat (2).

Disamping perlindungan terhadap jenis-jenis hak cipta pada Pasal 23, Pasal 24, dan Pasal 2, sebagaimana diuraikan diatas, terdapat ancaman terhadap orang yang mengelola perdagangan dalam segala bentuk yang dengan sengaja dan mengetahui membiarkan penjualn dan/atau penggandaan barang hasil pelanggaran hak cipta dan/atau hak terkait di tempat perdagangan yang dikelolannya sebagaimana dimaksud Pasal 10 diancamn dengan hukuman pidana denda sebagaiman disebutkan Pasal 114.

Perbuatan lain yang diancam dengan pidana denda adalah setia orang yang tanpa persetujuan dari orang yang dipotret atau ahli warisnya melakukan penggunaan secara komersial, penggandaan, pengumuman, pendistribusian, atau komunikasi atas potret sebagaiman dimaksud pasal 12 untuk kepentingan reklame atau periklanan untuk penggunan secara komersial baik didalam media elektronik maupun non elektronik dipidana denda dengan sebagaiman ditetapkan Pasal 115.

Ancaman hukuman pidana juga ditujukan kepada Lembaga Manajemen Kolektif yang tidak memiliki izin operasional dari Menteri sebagaiman dimaksud Pasal 88 ayat (3) dan melakukan penarikan royalty diancam pidana dan/atau denda sebagaiman ditetapakan Pasal 119. 
Berdasarkan uiraian di atas didalam UUHC 2014 terdapat 16 macam jenis perbuatan atau kegiatan yang dikategorikan sebagai tindak pidana dibidang Hak Cipta yang diatur dalam UUHC 2014. Kesembilan jenis tindak pidana hak cipta tersebut merupakan delik aduan. Jadi pengak hukum tidak dapat begitu saja melakukan tindakan apabila tidak ada aduan dari pihak yang dirugikan.

\section{PENUTUP}

\subsection{Simpulan}

Dari uraian tersebut dapatlah dikemukakan beberapa simpulan berkaitan dengan implementasi kektentuan pidana dalam pelanggaran hak cipta, yakni :

1. Undang-Undang No. 28 Tahun 2014 tentang Hak Cipta (UUHC 2014) selain mengatur berkaitan dengan ganti rugi atas tuntutan perdata, juga dapat dilakukan tuntutan pidana sebagaiman disebutkan didalam Pasal 105.

2. Ketentuan pidana yang melindungi pencipta dari berbagai pelanggaran telah diatur sebanyak 16 jenis pelanggaran terhadap Pasal 23, Pasal 24, Pasal 25, Pasal 10, dan Pasal 12.

3. Didalam penegakannya, aparat penegak hukum masih melangalami kesulitan mengingat pelanggaran terhadap hak cipta bukan delik biasa melainkan delik aduan, sehingga aparat penegak hukum bersifat pasif. Hal ini menyebabkan ketidakefektifan dalam penegakan hukum terhadap hak kekayaan intelektual regim ha cipta.

\subsection{Saran}

1. Memeperhatikan sulitkan penegakan hukum terhadap pelanggaran hak cipta, maka disarankan para seniman untuk memiliki organsiasi yang mengurusi hak kekayaan intelektual para seniman atau pencipta.

2. Harus dilakukan perubahan KUHAP berkaitan dengan jenis barang bukti, yang belum mencantumkan media elektronik dpat sebagai barang bukti.

\section{DAFTAR PUSTAKA}

\section{Buku:}

Budi Santoso, 2008, Materi Hak cipta, disampaikan pada pelatihan PRESERTIFIKASI HKI KLINIK HARI Fakultas Hukum Universitas Diponegoro, Semarang . 
Barda Nawawi Arief, 1998, Beberapa Aspek Kebijakan Pengakan Dan Pembangunan Hukum Pidana, PT. Citra Aditya Bakti, Bandung.

Muhammad Djumhana dan R. Djubaedillah, 1997, Hak Milik Intelektual (Sejarah, Teori dan Praktiknya di Indonesia), Citra Aditya Bhakti, Bandung.

Muladi, 1995, Kapita Selekta Sistem Peradilan Pidana, Badan Penerbit Universitas Diponegoro, Semarang.

Satjipto Raharjo, 2007, Biarkan Hukum Mengalir, Penerbit Buku Kompas, Jakarta.

Sentosa Sembriring, 2002, Prosedur Dan Tata Cara Memperoleh Hak Kekayaan Inteltual, Penerbit Yrama Widya, Bandung.

Wihadi Wiyanto, Lampiran Makalah Penerapan Undang-Undang No. 19 Tahun 2002 Tentang Hak Cipta Dalam Rangka Memerangi Pembajakan.

Penerapan UU No. 19 tahun 2002 Tentang Hak Cipta Dalam Rangka Memerangi Pembajakan. Disampaikan pada Lokakarya Terbatas Masalah-Masalah Kepailitan dan Wawasan Hukum Bisnis Lainnya, Jakarta 1011 Februari 2004

\section{Sumber Lain:}

Abdussalam, Hukum Kepolisian Sebagai Hokum Positif Dalam Disiplin Hukum, Restu Agung, 2007. http://www.wipo.org

Prosiding Haki, Jakarta 10-11 Februari 2004. Hlm. 285

Prosiding Simposium Nasional Haki, 18 Desember 2003. Hlm. 15.

http://www.en.wikipedia.org/wiki/hakcipta 